\title{
Opportunities Seized: from Tolstóigh to Pelévin
}

\author{
Mark Ó Fionnáin
}

\section{Introduction}

From the earliest days of the Celtic Revival, various Russian authors began appearing in Gaelic guise. As the Irish language was finding its feet again after centuries of neglect and there was a movement underway to quickly produce new, written literature in a language which-apart from poetry and folk songs - had never been much cultivated in recent times, one of the easiest and quickest ways to do so was to translate: as the original text already existed, all that had to be done was to put it into Irish, and lo and behold, a short story, poem or novel instantaneously came into being in Irish. And thus, several of the major Russian authors of that era made it into print in many of the myriad publications at that time. ${ }^{1}$ The earliest translation would appear to be that of Lev Tolstoy from 1909, entitled An Maistin agus an Geampa Aráin 'The Imp and the Lump of Bread', and over the following years, Tolstoy would, numerically, seem to have been the most popular Russian author to be translated, with Chekhov not too far behind. Other major Russians who were presented to the Irish-language readership at that time included Pushkin, Turgenev and Dostoyevsky. This statement, however, does come with some necessary qualifications. The first of these is the fact that there was quite a lot of repetition of the stories translated, with a given story frequently undergoing several different versions over the years. The translations of Tolstoy, for example, include at least three versions each of two stories (Как Чертенок Краюшку Выкупал ${ }^{2}$ and Упустишь огонь, не потушишь ${ }^{3}$ ), and Pushkin's Пиковая Дама 'The Queen of Spades' also underwent three different versions.

1. See Ó Fionnáin (2015) for a more detailed listing of the Russian texts that appeared in Irish during this period, and for more general information on issues of translating into Irish, including from Russian, and the questions raised, see O’Leary (1994, 2004, 2011).

2. 'How a Little Devil Redeemed a Crust of Bread', but usually entitled 'The Imp and the Crust' or 'Promoting a Devil' in English. The first version produced was the translation from 1909 mentioned in the main text.

3. 'If You Miss the Fire You will not Quench it', but usually entitled 'Quench the Spark' or 'A Spark Neglected Burns the House' in English. 
There is also a further caveat involved. Most of these translations were merely described as being 'a translation of a story by ...', with no unambiguous statement regarding the original language, whether it was from the original Russian text or from an extant English translation. Examples from various publications include the following: "Sgeul on Ruisis: aistriu é seo ar Sgeul Ruiisise do cheap Anton Tchehov" 'A story from Russian: this is a translation of a Russian story composed by Anton Chekhov', "Fiachra Éilgeach' do chuir Gaedhilg air" 'Translated into Irish by 'Fiachra Éilgeach", or "Tolstoi na Rúise do scriobh, an "Seabhac" do chuir i nGaedhilg" 'Tolstoy of Russia wrote it, 'An Seabhac' translated it into Irish'. It is thus unclear how many of these translations were done from the actual Russian and how many from existing English versions. There have been, however, several Irish speakers who did know Russian and who did thus translate from the original text, and the aim of this paper is to take a brief look at some of these translations in order to see how these translators dealt with the problem of foreign names and nouns and to see what purpose, if any, they saw their translations as serving.

\section{Dia, Diabhail agus Daoine}

One of the first books to include translations of Russian authors was Father Gearóid Ó Nualláin's (1874-1942) Dia, Diabhail agus Daoine 'God, Devils and People', from 1922. Ó Nualláin was the author of the four-part Studies in Modern Irish, a series that looked at the grammar of Modern Irish and analysed it in painstaking detail. He continued in this vein in Dia, Diabhail agus Daoine, a collection containing five of his own compositions and two translations from Russian. Each story in this volume is accompanied by exhaustive grammatical notes and observations, as he clearly saw his texts as having a didactic goal as opposed to an entertainment purpose, in keeping with his previous publications. The two translations in the book from the Russian are Pushkin's 'Snowstorm' (entitled in Irish Sion agus Sneachta 'Bad Weather and Snow') and Tolstoy's 'What Men Live By' (An Fiosrú, literally 'The Visitation'). ${ }^{4}$

Ó Nualláin seizes the opportunity offered to him to provide his readership with copious endnotes containing a wealth of detailed insider knowledge on life and the customs in Russia at that time, including Russian culture ("Russian use of the word brat 'brother' sometimes means little more

4. It should be noted here that on the website ainm.ie, a compendium of more than 1700 biographies of people who had links with the Irish language, Dia, Diabhail agus Daoine is described as being "aistrithe ó shaothar Rúisise Leo Tolstoy" "translated from Leo Tolstoy's Russian work', even though there is only one story by Tolstoy. 
than the English 'friend' and can just mean 'kinsman'”, Ó Nualláin 1922: 93), food and drink ("kvas is a fermented drink made from rye and malt, or from rye-flour", ibid., 94), accommodation ("The stove, in the Russian peasant's house, is a large brick erection, the space on top forming a kind of loft, where several people would have room to lie down. It is, of course, a cosy spot", ibid., 94), units of measurement ("the verst is .66 of a mile and the equivalent of 500 sachine (i.e. 500x7 feet)", ibid., 108), items of clothing (a kaftàn is a "long, wide, old-fashioned overcoat worn by men", ibid., 108), linguistics ("The final consonant in... Russian spelling ... is sharpened in speech into the corresponding 'voiceless' sound", ibid., 94), and the literal translation of some Russian idioms ("M. mumbled something under her breath. - The Russian has "under her nose", ibid., 93; "they are as wax in the candle to me.' So the Russian. 'They are the light of my life' is the normal English way of expressing it”, ibid., 96).

Regarding nouns and proper names themselves, the movement of stress in Russian is highly problematic, with nine possible patterns for nouns alone. ${ }^{5}$ Any learner of the language thus has to not only learn the six cases in the singular and plural for any given noun, but learn the stress pattern for that one noun and then remember it in use. It is very much a challenge. Most translators (and thus, by extension, their translations) tend to ignore marking the stress in Russian nouns and names, instead letting the reader pronounce Russian names such as Tolstoy or Ivan any way they wish. It is, however, generally understood that in transcriptions from Russian "the marking of stress position [is] highly desirable" (Comrie and Corbett 1993: 55). Ó Nualláin, exceptionally for his era, clearly felt so as well and, continuing in his vein as a didactician, he helpfully places the stress on place names and nouns "for the convenience of the reader" (Ó Nualláin 1922: 107). It is not clear how convenient it actually is for the reader to be able to pronounce (fictitious) Russian placenames such as Ненарадово/ Nienaràdovo correctly, but an incorrectly placed stress in a Russian word would clearly worry such a man of pedantry and grammar. Unfortunately, Ó Nualláin's multiple pages of notes and comments on 'correct' Irish do somewhat distract from the joy of reading Pushkin or Tolstoy in Irish, ${ }^{6}$ a feeling that is echoed in Muiris Ó Droighneáin's later comments on other compositions of Ó Nualláin's that there is 'a trace of the coldness of the man of grammar and logic on the fingers of the author and translator' ("mar a bheadh iarracht

\footnotetext{
5. Ryan and Norman (1996: vii).

6. The translation of Pushkin takes up 20 pages and is accompanied by 6 pages of detailed notes; Tolstoy takes up 34 pages and also has 6 pages of notes.
} 
d'fhuairneamh fhir an ghraiméir agus na laoighice ar mhéireanna an ughdair agus an aistrightheora," Ó Droighneáin 1936: 66).

\section{Dánta Próis}

Another author who knew Russian and who translated from the original texts was Liam Ó Rinn (1886-1943). Earlier on in his career he translated two works by Tolstoy, namely 'God Sees the Truth but Waits' and 'A Prisoner of the Caucasus', although these were probably done from the English, and in the 1930s he produced several translations of stories by Chekhov. ${ }^{8}$ In 1933, however, his original translations of Ivan Turgenev's Стихотворения в Прозе, entitled Dánta Próis 'Prose Poems', was published. In his book Ó Rinn took an interest in correctly and accurately transliterating Russian for his reader. As such, Ó Rinn first presents his reader with a transliteration system, which he accredits to 'two Irish-speakers' ("beirt Ghaedhilgeoiri," Ó Rinn 1933: 7). He (ibid.) explains this by saying:

Is gnáth le gach éinne focail Rúisise do scriobh do réir foghraiocht a theangan féin i sli gur deacair uaireanta a cur thar n-ais sna litreacha Rúisise. Tá beirt Ghaedhilgeoirí, áfach, tar éis córus cruinn do cheapadh chun a scribhte i litreacha Rómhánacha agus is dá réir sin atá gach focal Rúisise sa leabhar so.

Everybody usually writes Russian words according to the phonetics of their own language in a way that makes it difficult at times to put them back into Russian letters. Two Irish-speakers, however, have come up with a precise system to write them in Roman letters and it is according to that system that every Russian word in this book is written.

These two Irish-speakers, however, were very outward-looking, and did not limit themselves to the traditional Irish alphabet and phonemes. Aside from Irish (to represent some of the vowel sounds), they borrowed from English (ch and sh for the sounds /t $\int /$ "mar atá sa bhfocal church" and / / "mar atá sa bhfocal sheep") and French (using $j$ for the traditional English $z h$, i.e. /3/, " $j$ mar $j$ sa bhfocal jour nó s sa bhfocal pleasure”). Ó Rinn, like Ó Nualláin, also points out the fact that Russian is devoiced at the end of words ("Deineann

7. Бог правду видит, да не скоро скажет appeared as Chionn Dia an Fhirinne, acht Feitheann and Кавказский пленник as Ina Phrisunach ar Shliabh Caucais. Both of these were printed in the newspaper Sinn Féin in July and August 1914. Ina Phrisúnach... was left unfinished. Chionn Dia an Fhirinne... was republished in So Súd (Ó Rinn 1953) after Ó Rinn's death.

8. Opamop 'The Orator' appeared as An Cainnteoir and Mapu 'The Bet' as An Geall in the periodical Humanitas in the early 1930s. An Cainteoir [sic] was also republished in So Súd. 
p, t, k, f, s agus sh de b, d, g, v, z agus j fé seach i ndeire focail do ghnáth"), but then goes into even more depth by mentioning the hard and soft signs

na consaini eile leathan ach amhain roimh ghuth chaol nó roimh an gcomhartha caol ('). Cuirtear an combartha leathan (') i ndiaidh consaine chun i dhéanamh leathan d'ainneoin caol-ghotha ina diaidh

the other consonants are broad except before a slender vowel or the slender sign ('). The broad sign (') is put after a consonant to make it broad despite a slender vowel coming after it.

(Ó Rinn 1933:7)

and broad and slender vowels (broad vowels are "broad at their front and end' "leathan ina dtosach agus ina ndeire", whilst slender vowels are "narrow at their front and broad at their end" "caol ina dtosach agus leathan ina ndeire"). Furthermore, even though it is not specifically mentioned in his transliteration system, Ó Rinn also adopts the method of showing the stressed syllables in Russian words and names, allowing the reader to correctly pronounce Tatíschev, Prokopóvich, Sumarokóv, Vorontsóva-Dáshkova, Zapiski Okhótnika, Mërtvyia Dúshi and Revizór, amongst others. ${ }^{9}$

Ó Rinn prefaces his translations with a 16-page brief overview of the history of Russian literature, and takes the opportunity afforded to make a few political and cultural points. He starts off by defending 'recent' events in Russia - and the Russians - from their (nameless) detractors, those who would call the Russians half-barbaric ("leath-bharbartha"), and who are dismissive of Russian's great noble literature, claiming that it had merely sprung up overnight ("fás aon-oíche an litríocht mhór uasal atá acu”). He also, however, sees in their literature a possible source of inspiration for the nascent Irish-language literature, especially in the case of translations, a theme close to Ó Rinn's heart: ${ }^{10}$

An mbuintir go bhfuil eagla orthu go ndéanfaidh mórán aistriúcháin diobháil do thréithe dúthchasacha litriochta na Gaedhilge cuimhnidis dá mhéid leabhar do haistriodh go Rúisis nár bhain sé pioc o dhüthchasaiocht litriocht na teangan san: biodh

\footnotetext{
9. However, his transliteration system as presented is not complete, since he does not give any indication to his reader what sound $\langle\ddot{e}\rangle / \mathrm{jo} /$, as in Mërtvyia Dúshi, is meant to represent, for example.

10. See Ó Fionnáin (2014) for a detailed look at Ó Rinn's interest and approach to translation and Daltúin (2013) for a general overview of Ó Rinn and his works, including his translations.
} 
a fhianaise sin ar litriocht Rúisise na naoú aoise déag-atá chó bunúsach agus chó düthchasach ar a laighead le haon litriocht dar cumadh in iarthar na hEorpa san aois chéanna. Brisfidh an düthchas tri shuilibh an chait Ghaelaigh, leis, ach foidhne bheith againn.

Those people who are afraid that too much translation will damage the native aspects of Irish literature, let them remember that however many books were translated into Russian, it did not take anything away from the nativeness of that language's literature: as proof of that there is the Russian literature from the 19th century, which is at least as basic and as native as any literature that was composed in western Europe in the same century. Everything will happen naturally in Irish as well, if only we are patient.

(Ó Rinn 1933:16)

He also seizes the opportunity to have a go at those who feel that Irish should remain pure and unsullied from foreign influences, especially in relation to the coinage of new words and neologisms: ${ }^{11}$

ach an dream a mholann dúinn focail iasachta do sheachaint . . ba chóir dóibh mhachtnamh ... d'ainneoin a usachta do sna Ruiiseánaigh focail nua do cheapadh as préamhacha a dteangan féin, gur beag scéal le Chékhov, cuir i gcás, atá glan ó fhocail iasachta... agus iad litrithe do réir foghraiochta.

but the people who advise us to avoid foreign words . . . should remember that ... however easy it is for Russians to invent new words from the roots of their own language, there are few stories by Chekhov, for example, which are unsullied by foreign words . . . and which are spelt phonetically.

(Ó Rinn 1933: 15-16)

On a less political note, he also states that he feels that Turgenev is not as good as Tolstoy or Dostoyevsky and does not move his reader as Chekhov does (ibid., 24-5). He also notes in a footnote that Ukraine is a separate 'nation' and that Ukrainian is a sweeter language than Russian ("Náisiún fé leith atá sa Rúis Bhig agus teanga acu is binne ná an Rúisis”, ibid., 20).

It is worth noting that the State publishers An Gum only accepted this

11. See Mag Eacháin (2014) for a detailed account of the issues at that time regarding the creation of new Irish terminology. 
book for publication due to the scarcity of original translations from Russian and not because the reading public might have much interest in it (Daltúin 2013: 210-1), although a review in The Cork Examiner (29 November 1933) did call it

Cnósacht de ghiotai beaga gleoite agus biodh gur deacair an ghleoiteacht go léir do thabhairt isteach sa Ghaedhilg agus an dul céadna do bheith air, is iongantach mar éirigh leis an aistrightheoir é dhéanamh. Tuilleann sé an moladh mór dá bharr.

A beautiful collection of small pieces and though it is difficult to bring all of the beauty across into Irish and have it have the same style, it is wonderful how the translator managed to do it. He deserves a lot of praise for this.

(cit. from Daltúin 2013:210)

\section{Maighréad Nic Mhaicín}

Most of the extant translations from Russian into Irish, however, were done by Maighréad Nic Mhaicín (1899-1983). ${ }^{12}$ In the 1930s she published translations of Chekhov's Вишнёвый Сад 'The Cherry Orchard' (1935) and a collection of Chekhov short stories entitled Gearr-Scéalta Cuid 1 'Short Stories Part 1' (1939), although no second part ever appeared; in the 1950s she published translations of Turgenev's Записки Охотника 'A Huntsman's

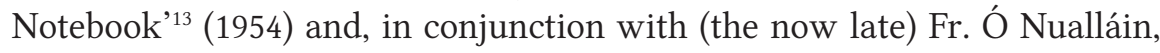
Scéalta ón Rúisis 'Stories from the Russian' (1955), a collection of four stories (two by Pushkin, one each by Tolstoy and Turgenev), with two translations contributed by her and two by Fr. Ó Nualláin.

Unlike Ó Nualláin and Ó Rinn, Nic Mhaicín provided no endnotes, footnotes, introductions, commentaries or, indeed, personal opinions, leaving the reader with pure, unadulterated stories in Irish. However, her translations are not totally apolitical in that she deviated from what had been the norm up until then of writing Russian names and words in

12. Nic Mhaicín was a graduate of Celtic Studies and French in Belfast and visited Russia in 1932 when studying the language. While there in 1935 she married Irishman Patrick Breslin. However, after Nic Mhaicín returned to Ireland to give birth to their child in 1938 she was not allowed back into the USSR, and the Soviet authorities would not permit Breslin to leave. He eventually died of ill health in a Soviet camp in Kazan' in 1942. In 1943 Nic Mhaicín became a lecturer in Russian at Trinity College, Dublin, retiring in 1969. For more on Nic Mhaicín, see Breatnach and Ní Mhurchú (1994:61-2).

13. However, this collection contains translations of only 14 of the original 25 Russian stories. 
one of the many available English ways and actually made an attempt at Gaelicising the names in use in her texts, thus trying to prove that Irish was just as capable of handling Russian names and nouns as any other Standard Average European language. ${ }^{14}$

Nic Mhaicín's approach involved one of two ways. She either (very) occasionally used an Irish version of the name in question, for example Áine in place of the original Russian Аня $/ \mathrm{an}^{\mathrm{j}} \mathrm{a} /$ in her translation of Вишнёвый Cad, or else she Gaelicised the spelling. In other words, she limited herself to the 18 letters of the traditional Irish alphabet, and tried to adhere to the 'caol le caol, leathan le leathan' spelling rule as far as possible.

This attempted Gaelicisation both worked and did not work. In the case of some of the easier, less problematic names, such as Tула 'Tula', there was no problem in inventing a Gaelic version like Túla (Nic Mhaicín 1954: 25, 209). ${ }^{15}$ With a name like Василий 'Vasiliy', she came up with Bheasaili (Nic Mhaicín 1939: 12), which, despite its awkward appearance, does give an approximate Irish pronunciation of the Russian. ${ }^{16}$ Less successful, though are many of her other attempts, for various reasons.

In the case of Лизавета 'Lizavyeta', for example, Nic Mhaicín solves the problem of the lack of a $\langle\mathrm{z}\rangle$ and $\mathrm{a}\langle\mathrm{v}\rangle$ in Irish by using an $\langle\mathrm{s}\rangle$ and the native Irish combination 〈bh〉, and thus Gaelicising the name as Lisabheta (Nic Mhaicín and Ó Nualláin 1954: 44). Unfortunately, this leads to a further problem of how to pronounce said $\langle\mathrm{s}\rangle$ : is it a slender $/ \int /$ due to the slender <i before it, a broad /s/ due to the broad <a〉 after it or, indeed, an English $\mathrm{z} /$, as in the name 'Elisabeth'? In the case of the name Kocms 'Kostya', rendered by Nic Mhaicín as Costia, how is her Irish <ia> to be pronounced? Is it /ja/ as in English or / $\mathrm{i}: \mathrm{a} /$ as in Irish? And in the case of a name, patronymic and surname coming together, the end result can get very much out of hand: Любовь Андреевна Раневская 'Lyubov Andreyevna Ranevskaya' from Вишнёвый Cad is Gaelicised by Nic Mhaicín as Liúbobh Andréembna Rainémhscáidhea, although this unwieldy mouthful immediately raises several questions regarding orthography and pronunciation. Why is the broad/slender orthographic rule broken? Why are both $\langle b h\rangle$ and $\langle\mathrm{mh}\rangle$ used

14. As one example of this variation, Чехов (Ch[y]ekhov) was variously written by Irishlanguage translators in the period in question as Tchekoff, Tchehov, Tsecheov, Tshechov, Chékhov, Tséchobh and Tsechobh.

15. The examples given in this section are a very small representative sample. A detailed analysis of all the names used in Nic Mhaicín's translations (and by others) is beyond the scope of this work.

16. However, in a later story Vasiliy is written as Bheasili, with a slender 〈s〉 giving / $/ \mathrm{J}$ (Nic Mhaicín 1954: 120, 133, 181). 
to represent /v/? Does the Irish sineadh fada accent show stress or a long vowel? These issues were not exclusive to names: nouns and place names were also Gaelicised, but with the same orthographic and phonetic problems. Kvas was Gaelicised as cmheas (Nic Mhaicín 1939: 9), whilst the placename Красное Село 'Krasnoye Syelo’ appeared as Crasnoidhe Seló (Nic Mhaicín and Ó Nualláin 1955: 7).

As Nic Mhaicín's texts were also published in the Gaelic font, we are left with a situation where the potential Irish-language reader deliberately chooses to read these stories in Irish as opposed to the readily-available English-language version, in the Gaelic font, and in beautiful idiomatic Ulster Irish, but then has to decide whether to give the names in the text an Irish pronunciation or an English one or, indeed, a mixture of both. However, to give her her due, Nic Mhaicín, unlike Ó Rinn and Ó Nualláin, seems to have totally eschewed English letters for their Irish phonetic equivalents; for example, instead of the 'English' $\langle\mathrm{v}\rangle$ she consistently uses $\langle\mathrm{bh}\rangle$ or $\langle\mathrm{mh}\rangle$ all the way throughout, and in this she was more successful and less inconsistent than other authors. Ris[t]eárd Ó Foghludha, for example, in his translation (probably from the English) of Chekhov's The Bear (Ó Foghludha 1923) gives us Popobha as the surname of one of the main characters, with an Irish $\langle\mathrm{bh}\rangle$ representing the traditional $\langle\mathrm{V}\rangle$, but we are then told that it is a play by Chekhov, with the traditional English spelling. The pedantic and hyper-correct Fr. Ó Nualláin (Nic Mhaicín and Ó Nualláin 1955: 96) presents us with Avdotya Semeonobhna in one of his translations, thereby giving a combination of a 'foreign' $\langle\mathrm{v}\rangle$ and $\langle\mathrm{y}\rangle$ and the native Irish $\langle\mathrm{bh}\rangle$ and $\langle\mathrm{eo}\rangle$ in the one name.

A new book of translations of Russian authors into Irish - Scéalta ón Rúis (Mac Annraoi 2016) - has recently been published, although since they have been translated from English they will not be covered in this paper. However, the translator, Risteárd Mac Annraoi, has Gaelicised the names, presenting the reader with the likes of Gógal (Gogol'), Gointearov (Goncharov), Pilniac (Pilnyak) and Túirgéiniev (Turgenev), amongst others. As can be seen, he eschews the Irish $\langle\mathrm{bh}\rangle$ for $\langle\mathrm{V}\rangle$, which is now acceptable in foreign words, and also avoids 'foreign' sounds by using, for example, 〈s〉 for $\langle\mathrm{z}\rangle$ and a slender $\langle\mathrm{t}\rangle$ for $\langle\mathrm{ch}\rangle$, e.g. Замятин (Zamyatin) is Gaelicised as Saimiaitin. Other authors given include Baibil (Babel), Dostaidheivscí (Dostoyevsky), Púiscin (Pushkin), Téachov (Chekhov) and Tolstái (Tolstoy). What is of more interest to us here is that Mac Annraoi also reproduces some of the earlier works by Ó Rinn and Nic Mhaicín, including Nic Mhaicín's An Bhanrion Spád. However, he not only rewrites the title of her translation as An Bhanrion Spéireata (Nic Mhaicín and Ó Nualláin 1955:39-67) and 
standardises a lot of the northern Irish forms she used, he also 'improves' on her attempts at Gaelicisation, giving the reader Liosaivéata Iavanóvna, for example (Mac Annraoi 2016:107-137).

\section{Amón-Rá}

Regarding Modern Irish's orthography, Campbell makes the bold and brave statement that "Irish has one of the least efficient writing systems in use" (1991: 632) ${ }^{17}$ and whilst this is patently untrue, Irish orthography would appear not to be ideally suited to transliteration, as can be seen from Nic Mhaicín's brave and honourable failures above. In his foreword to Rashoomon, translations of several stories from Japanese into Irish, the translator Seán Ó Dúrois also reckons that Irish spelling is not suited to transliterating, and resorts to the common transliterated English version of names and places (Ó Dúrois 1995: 14-5). This is also the tack taken by Ó Fionnáin, stating in his introduction to Folcadán Airciméidéis, his translations of works by Kharms and Vvedénskii, that

D'fhéadfainn na focail agus na hainmneacha Rúisise sa téacs a litriu de réir chóras fuaimnithe na Gaeilge, ach chonacthas dom go mbeadh leithéidi Puiiscín, Tolstói nó Vvieideanscaí ró-aduain dóibh siúd atá cleachtach cheana féin don léitheoir, go háirithe má tá sé cleachtach cheana féin ar leithéidí Pushkin, Tolstoi srl...

I could have spelt the Russian words and names in the text according to the sound system of Irish, but it seemed to me that the likes of Púiscin, Tolstói or Vvieideanscai would be too strange for those which are already used by the reader, especially if they are used to the likes of Pushkin, Tolstoi, etc...

(Ó Fionnáin 2004: vii-viii)

This is also the approach taken in Ó Fionnáin's translation of Victor Pelevin's Омон $\mathrm{Pa}$ (2012). ${ }^{18}$ The titular character's first name is taken from the acronym for the Russian riot police, OMON (Отряд Милиции (now Мобильний) Особого Назначения 'Special Purpose Militia (now Mobile) Unit').

17. This statement seems to have been expunged from later editions, however. In any case, the description of Irish itself in Campbell's book has several errors in spelling, even in the later editions, such as mòr, na hein, De hAoine, aran, seachtan, and questionable grammatical forms, e.g. dosna clochaibh, tá thú ag obair, and should therefore in any case be approached with caution.

18. This is the most common Anglicised version of his name (Виктор Пелевин). Ó Fionnáin writes it in Irish as Víktor Pelévin, marking the stress positions in the name. 
His second name is taken from the Egyptian sun god Ra. Thus, at first sight his name seems to consist of two separate units. However, this name also contains a third linguistic pun. Although it transliterates into English as <omon ra〉, the correct pronunciation is /amon ra/, with an /a/ instead of the first, expected, /o/, and if pronounced in this way the reader will see (or, more probably, hear) the link to the great chief Egyptian god Amon-Ra. ${ }^{19}$ This linguistic pun is only available to those who pronounce the first <0〉 of the name as an /a/ in accordance with the rules of Russian stress and phonetics. Therefore, to be fully aware of the three meanings of the name, i.e. the riot police, the sun god Ra and the god Amon-Ra, the name, when given in a translation, should convey the very same information as far as possible. As the OMON is only known in Russia, any translation would need to explain the reference. Andrew Bromfield's 1994 English version has the following on the back cover: "his name combines the Russian word for special police force and the Ancient Egyptian sun god”, whilst the Polish translation explains the reference in a footnote ("Otdiet [sic] milicyi osobogo naznaczenija-Specjalny Oddziat Milicji”, Rojewska-Olejarczuk 2007: 7). Neither of these two examples manages to convey the triple pun contained in the name. Ó Fionnáin, however, in an effort to impart to his Irish readers the triple meaning has added a sentence to the text, which reads: "Ainmniodh mé as an Arm Milisteach d'Ócáidi Neamhghnácha" 'I was named for the Militia Army for Special Occasions' (Ó Fionnáin 2012:1), thus linking the protagonist's name with the special police force and, if the reader is au fait with the official Irish versions of Egyptian mythological names for deities, both Ra and Amon-Ra.

Regarding Omon's brother, Ovir, who was meant to become a diplomat and whose name is the acronym for the Russian Отдел Виз и Регистрации 'The Department of Visas and Registration', different approaches are again employed: Bromfield ignores it totally, whilst Rojewska-Olejarczuk (2007: 8) once more explains this in a footnote ("Otdiet wiz i riegistracyi-Wydziat Wizowo-Meldunkowy”). Ó Fionnáin, though, adds in extra information through a further rewriting of the text in order to, again, bring the Irish-language reader that bit of extra knowledge, rendering the brother's name in Irish as 'Arvac', from the initial letters of An Roinn Viosai agus Clárúcháin (Ó Fionnáin 2012:1-2). Regarding the translation/ explanation of these unique Russian names, Vernitski has more to say on the topic, regarding Bromfield's translation as a missed opportunity to give the English language reader further, deeper insight into the meaning of the names in the text (Vernitski 2000: 95),

19. Also variously spelt Amun-Ra or Amen-Ra in English. 
and stating with regard to 'Omon' and 'Ovir' that

The reader may wonder why this name [Omon] is not common, especially as on the same page the name of the protagonist's brother, Ovir (in Russian, the abbreviation for Visa Section), is given without its being stated in the text that this is an unusual name. The English reader may well assume that neither name has any additional meaning.

A further complaint made by Vernitski is the lack of explanation as to who Aleksándr Matrósov was. As Omon is returning to Moscow in order to become a cosmonaut, the lorry he is travelling in stops in the woods so that the driver can answer the call of nature. As he does so, Omon hears the sounds of machinegun fire in the distance and asks the driver what it is. He is told that it is from the Aleksándr Matrósov Infantry School, and the journey then continues. The black humour, however, is that just as Omon attends a flight school named after Alekséy Merése'ef, a pilot who lost his legs in the Second World War, and thus all students must have their legs amputated in his honour, those who attend the school named after Matrósov must learn to be like their very own Second World War hero, who stopped German bullets with his body so that his colleagues could storm a German position. This is the unstated 'in-joke' for Russian readers and should ideally be somehow brought across in translations. However, this reference to Matrósov is totally omitted in Bromfield's translation, leaving the reader with a random incident in the woods, whilst the Polish text does reference Matrósov's name but offers no further information as to who he was or what he did, leaving it to the Polish reader to find out what the reference-and thus the humour - is. The Irish reader, however, is again treated to a further explanation in the text, thus hopefully bringing the point home or, at the very least, giving the Irish-language reader the opportunity to make the connection themselves (Ó Fionnáin 2012:33):

[An C]oláiste Oiliuna in Ómós don Laoch Cogaidh Aleksándr Matrósov a thuill clú agus cail as é féin a chaitheamh ar inneallghunna de chuid an namhad $i$ rith an Dara Cogadh Mór.

[The T] raining College in honour of the War Hero Aleksándr Matrósov who earned fame and renown for throwing himself on the enemy's machinegun during the Second World War. 
Vernitski feels that this lack of explanation in the English translation leaves the whole episode of machine guns firing at a military school very random and "more obscure and absurd" for the English-language reader (and, indeed, one could claim, for the Polish reader too). Overall, regarding Bromfield's translation, Vernitski (2000:98) feels that

These examples suffice to show how a work which could have become a landmark translation into English ..., a turning point in the Western appreciation of Russian culture, and which provide [sic] the ideal occasion to represent Pelevin to the English reading public became, instead, a missed opportunity.

Hopefully, however, this was an opportunity seized for the Irish-language reader. ${ }^{20}$

\section{Conclusion}

If the English translation of Омон $\mathrm{Pa}$ can be described as a series of "missed opportunities', the Irish-language translations of works from Russian have generally better served their readership, even if such translations are few and far between. In the case of those few translators who actually did translate from the original Russian into Irish, stress was marked on names and nouns, explanations were given in the text or as endnotes, the reader was provided with historical developments of literature, political and cultural points, and, in the case of Nic Mhaicín, a brave attempt was made to show that Irish was capable of transliterating Russian, just as well as other, non-minority languages could. The Irish-language translators, far from missing opportunities, seem to have eagerly seized any chances provided and run with them.

The John Paul II Catholic University of Lublin,

20. Indeed, Vernitski has a list of things about Bromfield's translation of Омон $Р a$ that he does not like and which he feels were missed opportunities, but a discussion of these and how they are dealt with in the Irish-language (and Polish) translation would be beyond the scope of this paper. As this paper has focused to a degree on the transliteration and handling of names in Irish translations from Russian, the discussion of Amón-Rá has been limited to examples of names. 


\section{References:}

Breatnach, D., \& Ní Mhurchú, M, 1994, Beathaisnéis 4: 1882-1982. [Biography 4: 1882-1982], Dublin.

Bromfield, A., trans., 1994, Omon Ra, London.

Campbell, G., ed., 1991, Compendium of the World's Languages, Volume 1, London.

Comrie, B., \& Corbett, G., eds., 1993, The Slavonic Languages, London.

Daltúin, M., 2013, Liam Ó Rinn (1886-1943). Scríbhneoir Cathrach agus Criticeoir Iarchoilineach [Liam Ó Rinn (1886-1943). Urban Writer and Postcolonial Critic], Unpublished PhD thesis, Dublin.

Mac Annraoi, R., trans., 2016, Scéalta ón Rúis [Stories from Russia], Dublin. Mag Eacháin, C., 2014, Téarmaíocht Ghaeilge na hAthbheochana [Irish Terminology of the Revival], Dublin.

Nic Mhaicín, M., \& Ó Nualláin, G., trans., 1955, Scéalta ón Rúisis [Stories from the Russian], Dublin.

Nic Mhaicín, M., trans., 1935, An Silin-Ghort le Anton tSechobh [The Cherry Orchard by Anton Chekhov], Dublin.

Nic Mhaicín, M., trans., 1939, Anton tSechobh: Gearr-Scéalta Cuid I [Anton Chekhov: Short Stories Part 1], Dublin.

Nic Mhaicín, M., trans., 1954, Scéalta Sealgaire [A Huntsman's Stories], Dublin. Ó Droighneáin, M., 1936, Taighde i gComhair Stair Litridheachta na NuaGhaedhilge ó 1882 anuas [Research on the History of Modern Irish Literature from 1882 onwards], Dublin.

Ó Dúrois, S., trans., 1995, Rashoomon, Dublin.

Ó Fionnáin, M. trans., 2004, Folcadán Airciméidéis [Archimedes’ Bath], Dublin. Ó Fionnáin, M., trans., 2012, Amón-Rá, Dublin.

Ó Fionnáin, M., 2014, Translating in Times of Turmoil: Liam Ó Rinn's Irish Language Translations of Adam Mickiewicz, Lublin.

Ó Fionnáin, M., 2015, 'Na Ceithre Máistrí: Chekhov, Turgenev, Tolstoy and Pushkin and the translation of Russian into Irish', in: Czerniak, T., Czerniakowski, M., and Jaskuła, K., eds., Representations and Interpretations in Celtic Studies, Lublin, 267-282.

Ó Foghludha, R., trans., 1923, An Béar [The Bear], Dublin.

Ó Nualláin, G., 1922, Dia, Diabhail agus Daoine [God, Devils and People], Dublin.

Ó Rinn, L., 1914a, 'Chíonn Dia an Fhírinne, acht Feitheann’ [God Sees the Truth, but Waits], Sinn Féin, July 11-August 1.

Ó Rinn, L., 1914b, 'Ina Phrisúnach ar Shliabh Caucais' [A Prisoner on Mount Caucas], Sinn Féin, August 8-22.

Ó Rinn, L., 1930, 'An Geall’ [The Bet], Humanitas 1 (3), 13-17. 
Ó Rinn, L., 1931, 'An Cainnteoir' [The Speaker], Humanitas 2 (1), 17-19.

Ó Rinn, L., 1933, trans., Dánta Próis le Ivan Turgenev [Prose Poems by Ivan Turgenev], Dublin.

Ó Rinn, L., 1953, So súd [This and That], Dublin.

O'Leary, P., 1994, The Prose Literature of the Gaelic Revival, 1881-1921: Ideology and Innovation, Pennsylvania.

O'Leary, P., 2004, Gaelic Prose in the Irish Free State, 1922-1939, Dublin.

O'Leary, P., 2011, Writing beyond the Revival. Facing the Future in Gaelic Prose, 1940-1951, Dublin.

Rojewska-Olejarczuk, E., trans., 2007, Omon Ra i inne opowieści [Omon Ra and other stories], Warsaw.

Ryan, W. F., and Norman, P., 1996, The Penguin Russian Dictionary, London. Vernitski, A., 2000, 'Viktor Pelevin and the Translation of Omon Ra: A Missed Opportunity', New Comparison 29, 87-98. 
